\title{
REVIEW
}

\section{Generating pancreatic $\beta$-cells from embryonic stem cells by manipulating signaling pathways}

\author{
Spyridon Champeris Tsaniras and Peter M Jones \\ Diabetes Research Group, Division of Reproduction and Endocrinology, King's College London, Hodgkin Building (2.10N), Guy's Campus, \\ London SE1 1UL, UK \\ (Correspondence should be addressed to S Champeris Tsaniras; Email: spyridon.champeris-tsaniras@kcl.ac.uk)
}

\begin{abstract}
Type 1 diabetes results from an insufficiency of insulin production as a result of autoimmune destruction of the insulin-secreting pancreatic $\beta$-cells. It can be treated by transplantation of islets of Langerhans from human donors, but widespread application of this therapy is restricted by the scarcity of donor tissue. Generation of functional $\beta$-cells from embryonic stem (ES) cells in vitro could provide a source of an alternative graft material. Several ES cell differentiation protocols have reported the production of insulin-producing cells by mimicking the in vivo developmental stages of pancreatic organogenesis in which cells are transitioned through mesendoderm, definitive endoderm, foregut

endoderm, pancreatic endoderm, and the endocrine precursor stage, until mature $\beta$-cells are obtained. These studies provide proof of concept that recapitulating pancreatic development in vitro offers a useful strategy for generating $\beta$-cells, but current differentiation protocols employ a bewildering variety of growth factors, mitogens, and pharmacological agents. In this review, we will attempt to clarify the functions of these agents in in vitro differentiation strategies by focusing on the intracellular signaling pathways through which they operate - phosphatidylinositol 3-kinase, transforming growth factor $\beta, \mathrm{Wnt} / \beta$-catenin, Hedgehog, and Notch.

Journal of Endocrinology (2010) 206, 13-26
\end{abstract}

\section{Introduction}

Type 1 (insulin-dependent) diabetes mellitus is a $\mathrm{T}$ cellmediated autoimmune disease resulting in the destruction of insulin-secreting $\beta$-cells which are found exclusively in the pancreatic islets of Langerhans (Eiselein et al. 2004). It is a complex disorder whose pathogenesis involves $\mathrm{B}$ and $\mathrm{T}$ lymphocytes, macrophages, dendritic cells, and $\beta$-cell autoantigens, as well as multiple environmental and genetic components (Mandrup-Poulsen 2003, Yoon \& Jun 2005). $\beta$-Cell destruction is thought to be induced by cytokines produced by activated $\beta$-cell-specific autoreactive T-cells (Eiselein et al. 2004). The ability of the endocrine pancreas to produce insulin decreases until insulin production is no longer sufficient to maintain whole-body glucose homeostasis, at which point the patient presents with the clinical symptoms of type 1 diabetes. In brief, reduced circulating insulin causes decreased cellular uptake of glucose by peripheral tissues as well as hepatic overproduction of glucose, both of which result in hyperglycemia and the associated glycosuria, polyuria, and polydipsia. In the UK, type 1 diabetes affects 〜15-20 per 100000 individuals a year with a relative increase in incidence around 3\% yearly. Worldwide, the increase in incidence ranges around the same levels, indicating that it will be $40 \%$ higher in 2010 compared to 1998 (Onkamo et al. 1999).

A substantial amount of research has focused on providing a permanent cure for diabetes by replacing the lost $\beta$-cells. At present, the most promising new therapies are based on replenishing the $\beta$-cell mass. The development of the Edmonton protocol for pancreatic islet transplantation proved that cadaveric human islets can be grafted to diabetic patients using a minimal, glucocorticoid-free immunosuppressive regimen and provide insulin independence, if only for a limited period of time (Shapiro et al. 2000, Ryan et al. 2005). However, the shortage of cadaver pancreata for islet isolation has resulted in the search for alternative sources of insulinproducing cells.

A variety of pluripotent cell types have been suggested as potential starting material from which to generate an unlimited supply of insulin-secreting cells (see Seaberg et al. 2004, Suzuki et al. 2004, Hori et al. 2005), but this review will focus on the progress that has been made using embryonic stem (ES) cells (Evans \& Kaufman 1981, 
Thomson et al. 1998). This area of research was initiated around a decade ago by proof-of-concept studies demonstrating the generation of insulin-expressing cells from mouse ES (mES) cells (Soria et al. 2000, Lumelsky et al. 2001). Lumelsky et al. (2001) described the first culture-based protocol for the in vitro generation of pancreatic cells from mESCs using a fivestep protocol that was reported to generate insulin-expressing cells by selecting for nestin-positive progenitor cells. The reliability of this strategy was subsequently questioned when it was suggested that the insulin expression reflected uptake of insulin from the culture medium rather than de novo synthesis associated with insulin gene expression (Rajagopal et al. 2003, Hansson et al. 2004, Sipione et al. 2004, Paek et al. 2005). Despite this, several other groups modified the initial Lumelsky protocol and reported improved $\beta$-cell differentiation, although these protocols should be treated with some caution. For example, Hori et al. (2002) treated mESCs with an inhibitor of phosphatidylinositol 3-kinase (PI3K) and reported improved results over the original Lumelsky protocol. In a similar approach, Ku et al. (2004) increased the number of insulin-positive cells by the inclusion of activin $\beta \mathrm{B}$, exendin-4, and nicotinamide to the culture medium.

Other groups tried to direct the differentiation of the $\mathrm{mES}$ cells by overexpressing transcription factors critical for $\beta$-cell development, such as $P d x 1$ (Blyszczuk et al. 2003, Miyazaki et al. 2004), Pax4 (Blyszczuk et al. 2003), or Nkx2-2 (Shiroi et al. 2005), and reported the generation of insulin-expressing cells. This approach seemed to be the most promising strategy until recently, when safety concerns over therapeutic applications of genetically modified cells (Strulovici et al. 2007) led to a shift towards inducing differentiation solely by exposure to extracellular factors. D'Amour et al. at Novocell developed an in vitro differentiation protocol (Novocell protocol) using human ES cells (hESCs) that mimicked the in vivo developmental stages of pancreatic organogenesis. Thus, the aim was to provide sufficient cues to enable cells to transition through mesendoderm, definitive endoderm (DE), gut tube endoderm, pancreatic endoderm, and endocrine precursor stages, resulting in insulin-expressing cells with a reported insulin content approaching that of adult islets (D'Amour et al. 2006). Since then, several other groups devised similar differentiation protocols addressing the main developmental stages of the endocrine pancreas, especially definitive and pancreatic endoderm (Schroeder et al. 2006, Blyszczuk \& Wobus 2007, Jiang et al. 2007a,b). More recently, the Novocell group has applied their protocol to generate endocrine precursors in vitro, and then grafted these progenitors into diabetic mice to promote their full maturation (Kroon et al. 2008), generating cells that secreted insulin at levels comparable to mature $\beta$-cells.

These proof-of-concept studies demonstrate that recapitulating in vitro the signals controlling the development of the endocrine pancreas in vivo offers a promising strategy for $\beta$-cell generation. To date, published $\beta$-cell differentiation protocols have used a bewildering variety of growth factors, mitogens, and pharmacological agents that act by exerting transcriptional control on the developmental process. Table 1 lists some of these differentiation agents, their cellular targets and, where known, their site of action in the differentiation process. In this review, we will attempt to clarify the use of these media supplements by focusing on the specific signaling pathways through which they operate, predominantly the $\mathrm{PI} 3 \mathrm{~K}$, transforming growth factor $\beta$ (TGF $\beta)$, Wnt/ $\beta$-catenin, Hedgehog, and Notch pathways. Understanding the roles of these pathways in the differentiation of ES cells to functional $\beta$-cells will enable the future development of more precisely defined and efficient in vitro differentiation protocols.

\section{Modulators of signaling pathways}

\section{The PI3K signaling pathway}

PI3Ks are a group of lipid kinases that have been implicated in numerous cellular processes controlling proliferation, apoptosis, DNA synthesis, cytoskeletal rearrangements, and cell migration. They are defined in three classes, based on their catalytic subunit. Class I are heterodimers, incorporating a catalytic as well as a regulatory subunit. Class II have a distinct C-terminal C2 domain, whereas Class III are the homologs of the yeast Vps34p protein. Once activated, PI3K generates the second messenger molecules phosphatidylinositol 3-phosphate, phosphatidylinositol 3,4-biphosphate, and phosphatidylinositol (3,4,5)-triphosphate. These molecules, in turn, transmit the signals downstream through various mediators, such as AKT and glycogen synthase kinase$3 \beta$ (GSK-3 $\beta$; reviewed by Vanhaesebroeck et al. (2001)).

PI3K signaling and the generation of $\boldsymbol{\beta}$-cells The PI3K signaling pathway has been shown to negatively regulate cellular differentiation in human and murine ES cells. Initially, this pathway was shown to be important in maintaining selfrenewal of mESC cells through LIF-activated signaling (Paling et al. 2004). Consistent with this, it was later shown that activation of Akt, a major downstream component of this pathway, had similar effects in maintaining the pluripotency of murine and primate ES cells (Watanabe et al. 2006). More recently, McLean et al. (2007) have showed that suppression of PI3Ks facilitated the differentiation of hESCs into mesendoderm and DE under conditions in which activin-Nodal signaling was high. In an earlier study, suppressing the PI3K pathway was reported to promote endocrine differentiation of human fetal pancreatic cells (Ptasznik et al. 1997), perhaps suggesting an additional negative regulatory action of PI3K at a later stage in the $\beta$-cell differentiation pathway.

Modulators of the PI3K signaling pathway The involvement of PI3K signaling in ES cell differentiation suggests that manipulation of this pathway may enhance ES cell differentiation towards a pancreatic lineage, with PI3K inhibitors being used at an early stage to specify DE and/or at a later stage to promote differentiation of endocrine 
Table 1 Biologically active factors that have been reported to influence pancreatic endocrine differentiation in established embryonic stem (ES) cell differentiation protocols, with the reported mode of action (if known)

Target

\section{Compound}

Activin A

TGF $\beta$

PI3K

PI3K

Wortmannin

AKTI-II

TGF $\beta 2$

IDE1, IDE2

Wnt $3 \alpha$

Activin $\beta B$

FGF2 (bFGF)

HIP

Cyclopamine, KAAD-cyclopamine

DAPT

GLP-1, exendin

Retinoic acid

Retinoic acid signaling

\section{IGF2}

Indolactam V

Nicotinamide

IGF

PKC

poly(ADP-ribose)
Species

Human, mouse

Human, mouse

Human, mouse

Human

Mouse

Human, mouse

Human

Mouse, human

Mouse

Mouse

Human, mouse

Human

Mouse, rhesus monkey, human
Acts as late stage maturation factor and/or ME and DE inducers

Acts as late stage maturation factor and/or DE inducer

ME and DE inducers

Increases percentage of $P d x 1+$ cells

DE inducers

ME inducer

Increases percentage of $P d x 1+$ and insulin + cells

Acts to expand pancreatic progenitors and/or promote a pancreatic fate

Increases $P d x 1$ and insulin expression

Increases $P d x 1$ and insulin expression

Slight increase in Ngn3 expression

Increases insulin and $P d x 1$ expression and insulin + cells

Induces $P d x 1$-expressing foregut endoderm
Acts as a late stage maturation factor

Induces $P d x 1$ expression

Acts as a late stage 'maturation' factor
Sodium butyrate

$\beta$-Cellulin
HDAC

Mouse, human
Human

EGF Human

References

Kubo et al. (2004), D'Amour et al. (2005), Tada et al. (2005), Yasunaga et al. (2005), Jiang et al. (2007a,b), McLean et al. (2007), Phillips et al. (2007), Cho et al. (2008) and Zhang et al. (2009)

Hori et al. (2002) and McLean et al. (2007)

Hori et al. (2002) and Zhang et al. (2009)

McLean et al. (2007)

Shiraki et al. (2005)

Borowiak et al. (2009)

D'Amour et al. (2006), Cho et al. (2008) and Kroon et al. (2008)

$\mathrm{Ku}$ et al. (2004) and Frandsen et al. (2007)

Lumelsky et al. (2001), Miyazaki et al. (2004), Segev et al. (2004), Shi et al. (2005) and Jiang et al. $(2007 a, b)$

Mfopou et al. (2007)

Skoudy et al. (2004), D'Amour et al. (2006), Serafimidis et al. (2008) and Cho et al. (2008)

D'Amour et al. (2006), Phillips et al. (2007) and Cho et al. (2008)

Ku et al. (2004), Lester et al. (2004), Bai et al. (2005), Yue et al. (2006), Cho et al. (2008), Hui et al. (2009) and Zhang et al. (2009)

Micallef et al. (2005), D'Amour et al. (2006), Jiang et al. (2007b), Nakanishi et al. (2007), Shim et al. (2007), Cho et al. (2008), Kroon et al. (2008), Johannesson et al. (2009) and Zhang et al. (2009)

Jiang et al. (2007a) and Phillips et al. (2007)

Chen et al. (2009)

Hori et al. (2002), Vaca et al. (2003), Ku et al. (2004), Jiang et al. (2007a,b), Cho et al. (2008), Naujok et al. $(2008 a, b)$ and Zhang et al. (2009)

Goicoa et al. (2006), Jiang et al. $(2007 a, b)$ and Haumaitre et al. (2008)

Cho et al. (2008) 
precursors. Consistent with this, Hori et al. (2002) were the first to show that two direct pan inhibitors of the PI3K enzymes, LY294002 and wortmannin, enhanced endocrine differentiation of mESCs when used at the final stage of the differentiation protocol. More recently, Zhang et al. (2009) have used wortmannin to specify DE from hESCs, while in another study, an isoform-specific AKT inhibitor (AKTI-II), as well as LY294002, was able to drive differentiation of hESCs into DE (McLean et al. 2007).

A number of other PI3K pan inhibitors have not yet been used in pancreatic differentiation protocols, including ZSTK474, PX-866, and SF1126, nor have a number of isoform-specific PI3K inhibitors, including imidazopyridine-related compounds, morpholino-substituted pyridopyrimidine, quinolone and benzopyranone derivatives, quinazolinones and methylxanthines (Ward et al. 2003, Ito et al. 2007). The PI3K pathway can also be targeted at different sites. Compounds such as AKTI-1, AKTI-1,2, and staurosporine have been shown to inhibit the AKT mediator (Barnett et al. 2005). Other agents such as rapamycin and its derivatives can target MTOR, which is a downstream component of AKT (Tsang et al. 2007), although targeting downstream pathway components may be less effective than direct inhibition of PI3K.

\section{The TGF $\beta$ signaling pathway}

The TGF $\beta$ signaling pathway is complex, involving almost 30 different growth and differentiation factors. The signaling molecules belonging to the TGF $\beta$ superfamily have been subdivided into several subgroups, such as the bone morphogenetic protein, the Nodal, and the TGF $\beta$ subgroups. This pathway has been implicated in numerous cellular processes including proliferation, differentiation, apoptosis, cell migration, and adhesion (Massagué \& Chen 2000). TGF $\beta$ signaling is mediated through two types of transmembrane serine/threonine kinase receptors, namely type I and type II. Binding of TGF $\beta$ family members to type II receptors results in phosphorylation and activation of type I receptors. Once activated, type I receptors phosphorylate specific intracellular mediators known as SMAD proteins, which act as signal transducers and translocate to the nucleus, where they regulate gene transcription (Massagué 1998).

TGF $\beta$ signaling and the generation of $\boldsymbol{\beta}$-cells The TGF $\beta$ pathway is central to the generation of mesendoderm and DE. Nodal ligands, which signal through the ActrIb (listed as Acvr1b in the MGI Database) and ALK7 type I receptors as well as the ActrIIa (Acvr2a) and ActRIIB type II receptors (Schier \& Shen 2000), are thought to act as mesendoderm inducers. Thereafter, mesendoderm commitment to mesoderm or DE is thought to depend on the level of Nodal signaling, with high levels promoting an endodermal fate (Tremblay et al. 2000, Vincent et al. 2003). However, it is important to note that Nodal signaling can specify DE only when PI3K signaling is low, as described in section 'PI3K signaling and the generation of $\beta$-cells' (D'Amour et al. 2005, McLean et al. 2007). The Nodal pathway can also be activated by activin, which is known to signal through the same receptors (Chen et al. 2006). Consistent with this, several studies have shown that exogenous administration of activin A promotes DE differentiation of both mouse (Kubo et al. 2004, Tada et al. 2005, Yasunaga et al. 2005) and hESCs (McLean et al. 2007). As a result, this compound has been incorporated into several pancreatic differentiation protocols and, in conjunction with low PI3K signaling, has served as a first step to drive pluripotent cells towards DE formation (Shi et al. 2005, D'Amour et al. 2006, Jiang et al. 2007a,b, Phillips et al. 2007, Cho et al. 2008, Zhang et al. 2009).

Little is known about the possible roles of other TGF $\beta$ family members in promoting pancreatic differentiation. It was reported some time ago that TGF $\beta 1$ (TGFB1) enhanced the development of endocrine cells from mouse pancreatic fetal cells, with a more pronounced increase in $\beta$ - and PP-cells (Sanvito et al. 1994), and this effect was subsequently reproduced by Tei et al. (2005). Another study showed that TGF $\beta 2$ (TGFB2) induced differentiation of mESCs into $P d x$ 1-expressing endodermal cells (Shiraki et al. 2005), but several other growth factors from this family, including TGF $\alpha$ and TGF $\beta 1$, did not have any significant effect on promoting $P d x 1$ expression. In addition, the $P d x 1$-expressing cells induced by TGF $\beta 2$ expressed endodermal markers, but did not express insulin or glucagon, suggesting that TGF $\beta 2$ may be useful to promote an endodermal fate at an early stage in a differentiation protocol, whereas TGF $\beta 1$ may be useful after the specification of pancreatic or endocrine progenitors to enhance development of endocrine cells.

The importance of TGF $\beta$ signaling in defining DE was supported by a recent study in which two small molecules, named IDE1 and IDE2, were shown to direct differentiation towards the endodermal lineage with very high efficiency (Borowiak et al. 2009). Both molecules act by activation of the TGF $\beta$ signaling pathway, through SMAD2 phosphorylation, to drive $\sim 80 \%$ of $\mathrm{mESCs}$ and $60 \%$ of hESCs into DE, a higher efficiency than that achieved by activin $\mathrm{A}$.

\section{The Wnt/ $\beta$-catenin signaling pathway}

The Wnt/ $\beta$-catenin pathway (Fig. 1) plays a key role in the development of many organs such as brain (McMahon \& Bradley 1990, McMahon et al. 1992), kidney (Kispert et al. 1998, Itäranta et al. 2006), and pancreas (Wells et al. 2007). This pathway is activated when Wnt ligands bind to specific cell surface receptors, called frizzled (Fzd), leading to activation of the intracellular $\mathrm{Ca}^{2+}$, the planar cell polarity, or the $\beta$-catenin/canonical branch of the pathway. In the latter case, Fzd activation induces phosphorylation of intracellular proteins called dishevelled (Dvl), which, in turn, block the action of the GSK-3 $\beta$ enzyme which normally phosphorylates $\beta$-catenin. As a result of this, unphosphorylated $\beta$-catenin accumulates in the cytoplasm and is translocated into the nucleus, where it forms a complex 


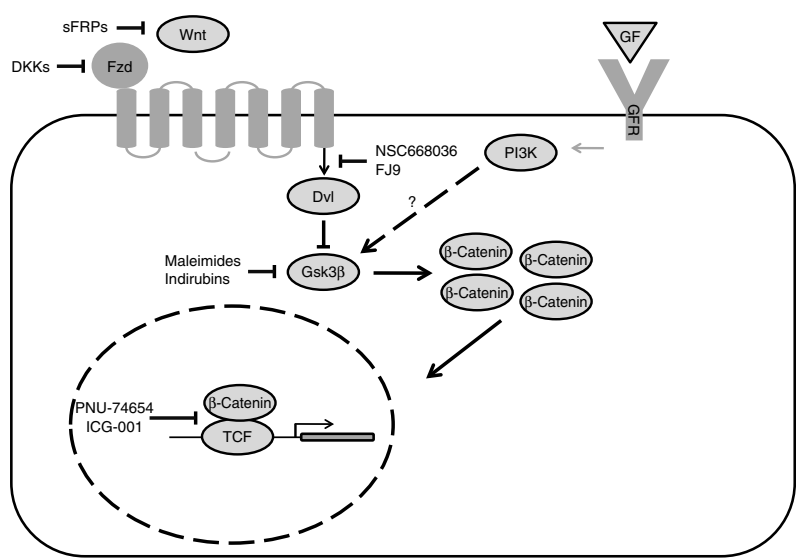

Figure 1 The Wnt signaling pathway. Wnt ligands bind to the frizzled receptor (Fzd) and activate the cytoplasmic protein dishevelled (Dvl) to inhibit the activity of glycogen synthase kinase$3 \beta$ (GSK3 $\beta$ ) or GSK3B. Gsk3 $\beta$ phosphorylates cytoplasmic $\beta$-catenin, targeting it for degradation at the proteosome. Inhibition of GSK3 $\beta$ activity therefore stabilizes the cytoplasmic pool of $\beta$-catenin, some of which then translocates to the nucleus to interact with members of the T-cell factor (TCF) family of transcription factors, leading to changes in the transcription of Wnt target genes. A variety of growth factors (GF), such as insulin, insulin-like growth factor 1, and epidermal growth factor, bind to specific receptors (GFR) and activate phosphatidylinositol 3-kinases (PI3K), which can interact with the Wnt signaling pathway at the level of GSK3 $\beta$. However, it is unclear whether the same subcellular pool of GSK3 $\beta$ can be targetted by both PI3K and Wnt. The schematic also shows pharmacological agents that influence developmental processes through actions at specific stages of the Wnt signaling pathway (see main text for details).

with T-cell factor (Tcf)/lymphoid enhancer factor (Lef) proteins (such as TCF1, LEF, TCF3, and TCF4), as well as co-activators, to activate transcription of target genes (Peifer \& Polakis 2000, Logan \& Nusse 2004).

GSK3 $\beta$ is also a component of the PI3K pathway, although it is unclear whether the same subcellular pool of GSK3 $\beta$ is targeted by both PI3K and Wnt. Several studies indicate that these two pathways crosstalk at the GSK3 $\beta$ level, suggesting that there is a single pool of the enzyme (Fukumoto et al. 2001, Almeida et al. 2005, He et al. 2007). However, a recent study has showed that GSK- $3 \beta$ could only be phosphorylated by PI3K when it is not bound to axin, whereas axin-bound GSK3 $\beta$ was dedicated to Wnt signaling ( $\mathrm{Ng}$ et al. 2009).

The Wnt/ $\beta$-catenin pathway and the generation of $\boldsymbol{\beta}$-cells Defining a precise role for Wnt signaling in the development of the endocrine pancreas is confounded by the complexity of the Wnt signaling pathway (Fig. 1), and the possibility of crosstalk between the canonical and noncanonical pathways. However, Wnt signaling has been implicated in both mesendoderm and foregut endoderm specification. Bakre et al. (2007) showed that activation of the pathway in mouse and hESCs causes mesendoderm-specific differentiation and generation of mesendodermal progenitor cells that can differentiate along various lineages. Similarly,
Marikawa et al. (2008) reported that Wnt/ $\beta$-catenin signaling was sufficient to induce the formation of mesendoderm in mouse embryonic carcinoma cells. In addition, a study by McLin et al. (2007) implicated Wnt signaling in foregut endoderm specification in Xenopus embryos. Thus, repressing Wnt signaling in the anterior endoderm was required for maintaining foregut fate, whereas high levels of Wnt signaling in the posterior endoderm enhanced intestinal development. They also postulated that Wnt factors from mesoderm can signal to the posterior endoderm to activate specific gene programs that inhibit foregut development, but cannot signal to the anterior endoderm, which is protected by secreting several Wnt antagonists. No similar studies have yet been carried out in other vertebrates, but several lines of evidence suggest that this is also the case in mice. For example, Wnt overexpression in the $P d x 1$ domain severely affects subsequent pancreatic development (Heller et al. 2002). In addition, deletion of Tff1 (listed as Hnf1a in the MGI Database) and Tof 4 causes defects in hindgut development (Gregorieff et al. 2004), whereas expression of $T f \mathcal{B}$ can be detected in the posterior but not the anterior DE (Merrill et al. 2004).

Modulators of the Wnt/ $\boldsymbol{\beta}$-catenin pathway Given its role in mesendoderm and possibly in foregut endoderm specification, Wnt signaling should be activated at an early stage in an ES cell differentiation protocol and inhibited at a later stage, whereas a sustained activation of the pathway would be expected to enhance the formation of mesendoderm. This could be accomplished by using purified natural or recombinant Wnt-secreted proteins. So far, only three studies have employed Wnt agonism to generate mesendoderm from hESCs, and all of them have used Wnt3a (D'Amour et al. 2006, Cho et al. 2008, Kroon et al. 2008). However, more than $20 \mathrm{Wnt}$-secreted proteins have been identified, but their mechanisms of action are not well understood and their effects can be cell type and tissue specific (Naylor et al. 2000). Proteins which signal through $\beta$-catenin, such as WNT1, WNT2, WNT3, and WNT3a (van Gijn et al. 2002), would be predicted to be useful in endocrine pancreas differentiation protocols. Moreover, small-molecule Wnt agonists could also prove useful for this purpose. A large number of GSK3 inhibitors have been reported. Examples include maleimides such as SB-216763 (Coghlan et al. 2000) and bis-7-azaindolylmaleimide (Kuo et al. 2003), indirubins such as indirubin- $3^{\prime}$-monoxime (Leclerc et al. 2001) and 6-bromoindirubin- $3^{\prime}$-oxime (Meijer et al. 2003), pyrazolopyrimidine and benzimidazole-pyrazolopyrimidine derivatives (Peat et al. 2004a,b) as well as lithium ions (Stambolic et al. 1996), AR-A014418 (Bhat et al. 2003) and CHIR 98014 (Ring et al. 2003). However, these are not specific to GSK3 $\beta$ and can also inhibit GSK3 $\alpha$ and other kinases, so more specific Wnt inhibition may be achievable by targeting other pathway components. For example, WAY316606 specifically inhibits the Wnt antagonist sFRP-1 (Bodine et al. 2009), whereas QS11 synergizes with Wnt3a by binding to and inhibiting an ARFGAP protein, possibly 
resulting in increased $\beta$-catenin translocation (Zhang et al. 2007). Another compound, named compound 1, has been shown to induce Wnt signaling in a GSK3 $\beta$-independent manner (Liu et al. 2005).

Although the available evidence also suggests an important role for Wnt suppression in the formation of posterior foregut endoderm, inhibition of the Wnt pathway has not yet been employed in in vitro differentiation protocols designed to generate endocrine pancreas. There is a long list of compounds that can inhibit this pathway at different levels. Some are endogenous secreted Wnt antagonists, including Dickkopfs (Dkks), Wnt inhibitory factor-1 (WIF-1), and secreted Fzd-related proteins (sFRPs). The most promising candidates include Dkk-1 and 4, which exert their actions by binding to a component of the Wnt receptor and preventing its activation, as well as sFRP2, sFRP3, and WIF-1, which bind to Wnt ligands (Kawano \& Kypta 2003). Several natural and synthetic small-molecule inhibitors have also been identified, primarily because of their potential use as anticancer agents. For example, a high-throughput screening assay identified six natural compounds which prevented the formation of the $\mathrm{Tcf} / \beta$-catenin complex, and the efficacy of these compounds was subsequently confirmed both in vitro and in vivo (Lepourcelet et al. 2004). Another Tcf/ $\beta$-catenin complex inhibitor, PNU-74654, was identified by virtual screening of 17700 synthetic compounds and shown to be active in vitro (Trosset et al. 2006). Another synthetic Wnt inhibitor, ICG-001, was reported to reduce Wnt signaling via binding to a transcriptional co-activator of $\beta$-catenin (Emami et al. 2004), while two other compounds, named NSC668036 and FJ9, were shown to disrupt the interaction between Fzd receptors and the Dvl PDZ domain (Shan et al. 2005, Fujii et al. 2007). The abundance of pharmacological modifiers of the Wnt signaling pathway (see Fig. 1) makes this an attractive target for inclusion in future in vitro differentiation protocols, as shown in Fig. 2.

\section{The Hedgehog signaling pathway}

The Hedgehog gene was identified almost 30 years ago and named after its ability to induce a hedgehog-like appearance in Drosophila (Nusslein-Volhard \& Wieschaus 1980). Subsequent studies led to the identification of the Hedgehog homologs in other species, including mouse and human (Marigo et al. 1995). In vertebrates, three secreted hedgehog proteins have been identified - Desert, Indian, and Sonic Hedgehog (Echelard et al. 1993) - and it is now known that these proteins play vital roles in directing cell differentiation during embryonic development and organ formation. Hedgehog signaling is initiated when one of these ligands binds to specific cell surface receptors called Patched (Ptc). This leads to activation of Smoothened (Smo), a G-protein coupled-like receptor. Thereafter, signaling is mediated through a multiprotein complex, the Hedgehog signaling complex, which modifies the activity of Gli transcription factors in order to regulate expression of target genes (Villavicencio et al. 2000).

\section{Hedgehog signaling and the generation of $\boldsymbol{\beta}$-cells} The Hedgehog pathway has an important role to play in early pancreas development. Repression of Sonic hedgehog expression in the foregut region is essential for specification of the pancreatic domain. This repression occurs through activin $\beta B$ and FGF2 signals, which are secreted by the notochord, thereby permitting expression of pancreatic transcription factors, such as $P d x 1$. Consistent with this, isolated notochord or purified activin $\beta B$ and FGF2 have similar effects when applied to foregut endoderm cultures ex vivo (Hebrok et al. 1998). In accordance with this, increased Hedgehog activity during development impairs pancreas formation (Apelqvist et al. 1997, Kawahira et al. 2005), while inhibition of Hedgehog signaling causes an enlargement in islet and pancreas mass (Kim \& Melton 1998, Hebrok et al. 2000). Hedgehog signaling may also be involved in the maintenance of pancreatic endocrine function. Thus, Thomas et al. (2000) used the INS-1 $\beta$-cell line to demonstrate that downregulation of hedgehog signaling decreased insulin secretion as a result of reduced insulin gene transcription. In a subsequent study, it was also shown that $P d x 1$, a key inducer of insulin expression, has Hedgehog-responsive regions within its promoter, and its expression is downregulated in the absence of Hedgehog. Conversely, ectopic Hedgehog expression was reported to increase both insulin and $P d x 1$ expression (Thomas et al. 2001).

Modulators of the Hedgehog signaling pathway The developmental evidence suggests a dual role for Hedgehog signaling in a differentiation protocol for the generation of endocrine pancreas, with an initial inhibition of the pathway

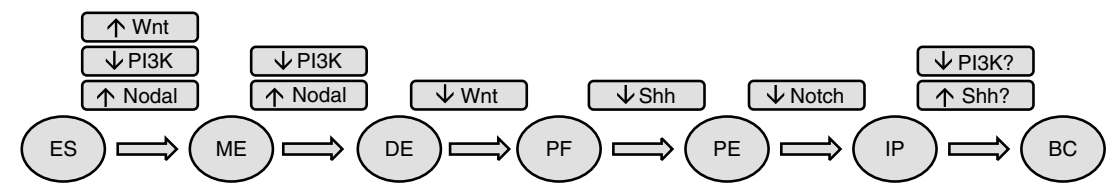

Figure 2 A proposed differentiation protocol for the generation of $\beta$-cells from embryonic stem cells. Manipulating the signaling cascades as shown is predicted to drive differentiation along the sequence of $\mathrm{ES}$, embryonic stem cells; $\mathrm{ME}$, mesendoderm; DE, definitive endoderm; $\mathrm{PF}$, posterior foregut; $\mathrm{PE}$, pancreatic endoderm; IP, islet precursors; $\mathrm{BC}$, insulin-expressing $\beta$-cells. The role of PI3 and Shh (sonic hedgehog pathway) at the final stage of differentiation is not well understood (see main text for details). 
at an early stage of ES differentiation, followed by reactivation at a later stage.

The optimal timing for Hedgehog inhibition would be after DE has formed and Wnt signaling has been downregulated. In accordance with this, Shh is highly upregulated during embryoid body formation and DE induction, leading to repression of $P d x 1$ expression (Mfopou et al. 2005, 2007), implying that Hedgehog inhibitors would be beneficial at this stage. However, it is not immediately apparent which inhibitors would be most effective. Thus, when the Hedgehog inhibitor activin $\beta \mathrm{B}$ was applied during a mESC differentiation protocol at a late stage, it was reported to increase the percentage of insulin-expressing cells $(\mathrm{Ku}$ et al. 2004). In a later study, the same compound was shown to induce expression of the $P d x 1$ gene in cultured hESCs, but at the same time increased Shh expression (Frandsen et al. 2007). These unexpected results might indicate that the effects of activin $\beta \mathrm{B}$ are cell and tissue specific, whereas its differentiation-promoting activity might be Hedgehog-independent. In contrast, FGF2 (or bFGF) has been used extensively in differentiation protocols to expand pancreas progenitors and promote a pancreatic fate (Lumelsky et al. 2001, Miyazaki et al. 2004, Segev et al. 2004, Shi et al. 2005, Jiang et al. 2007a,b). It should be noted, however, that the effects of FGF2 seem to be concentrationdependent. In chicks, low concentrations of FGF2 increased $P d x 1$ and insulin expression and downregulated Shh expression, whereas high concentrations had the opposite effects (Hebrok et al. 1998). Other Hedgehog repressors that have been used in differentiation studies include Hedgehoginteracting protein (HIP) and cyclopamine. HIP is an endogenous hedgehog modulator which reduces Hedgehog signaling by direct binding to Hedgehog proteins (Chuang \& McMahon 1999) and which has been reported to be efficient in increasing the percentage of insulin-positive cells in mESC cultures (Mfopou et al. 2007). Cyclopamine and its more potent derivative KAAD-cyclopamine are steroidal alkaloids known to block Smo, thereby preventing downstream signaling of the pathway (Taipale et al. 2000). Their efficiency has been demonstrated in both mouse (Skoudy et al. 2004, Serafimidis et al. 2008) and human pancreatic differentiation protocols (D'Amour et al. 2006, Cho et al. 2008). Several small-molecule inhibitors of the Hedgehog pathway could also prove useful in the derivation of $\beta$-cells from ES cells, including steroidal alkaloid inhibitors such as jervine, AY9944, triparanol, and U18666A (Cooper et al. 1998, Incardona et al. 2000). Chen et al. (2002) identified four naturally occurring small molecules (SANT-1 to 4) that were shown to directly inhibit Smo activity, as does a synthetic aminoproline named CUR61414 (Williams et al. 2003). Other agents, such as forskolin, 3-isobutyl-1methylxanthine, and dibutyryl-cAMP (db-cAMP), act by increasing the activity of protein kinase $\mathrm{A}$, which is known to antagonize Hedgehog signaling (Frank-Kamenetsky et al. 2002). Hedgehog downregulation was also shown to be promoted by JK184, an inhibitor of alcohol dehydrogenase
7 (ADH7), which is assumed to be correlated with Hedgehog signaling (Lee et al. 2007).

The reactivation of the Hedgehog pathway at a relatively late stage in the differentiation process may enhance insulin production after the endocrine progenitor stage. Hedgehog agonism can be achieved using purified recombinant $\mathrm{SHH}$, IHH, or DHH proteins, all of which have been used in vitro (Dyer et al. 2001, Mfopou et al. 2007). Synthetic small-molecule agonists have also been identified, including SAG and Hh-Ag 1·1-1.5. SAG is a chlorobenzothiophene, which acts as an agonist at low concentrations but as an antagonist at higher concentrations (Chen et al. 2002). Hh-Ag 1.1 was identified by screening a library of 140000 synthetic compounds and was reported to promote Hh signaling by stabilizing Smo. Subsequently, several other Hh-Ag 1.1 derivatives were synthesized. Hh-Ag 1.2 was shown to be the most stable, whereas $\mathrm{Hh}-\mathrm{Ag} 1 \cdot 3$ showed the lowest toxicity in embryonic tissue cultures (Frank-Kamenetsky et al. 2002). In addition, purmorphamine, a 2,6,9-trisubstituted purine molecule, is a Hedgehog agonist which is thought to act by activating Smo or another upstream protein (Wu et al. 2004).

\section{The Notch signaling pathway}

The notch signaling pathway is a critical regulator of tissue development and cell fate decisions during embryogenesis. This pathway acts by either inhibiting or inducing the spread of cellular differentiation, known as lateral inhibition or induction respectively. Notch signaling is also used in an iterative way to regulate consecutive cell fate decisions required for the formation of specialized tissues. Signaling is initiated when transmembrane Notch ligands, belonging to the Delta-Serrate-Lag2 family, bind to Notch receptors. Upon stimulation, the receptor is proteolitically processed by the sequential actions of two enzymes: tumor necrosis factor converting enzyme and $\gamma$-secretase, leading to the release of the Notch intracellular domain (NICD), which translocates to the nucleus and interacts with $\mathrm{CBF} 1 / \mathrm{SuH} / \mathrm{Lag} 1$ (CSL) transcription factors to initiate expression of target genes, including the basic helix-loop-helix Hes and Hey genes (Bray 2006).

\section{Notch signaling and the generation of $\boldsymbol{\beta}$-cells Notch} signaling is important for regulating the expression of neurogenin 3 (Ngn3 or Neurog3), a critical transcription factor for the formation of pancreatic endocrine cells. Ngn3expressing cells are considered to be islet progenitors (Apelqvist et al. 1999, Gu et al. 2002), and lack of Ngn3 expression leads to complete ablation of the endocrine component in developing mice (Gradwohl et al. 2000). Notch signaling represses transcription of $\mathrm{Ngn} 3$ through Hes activation to prevent premature endocrine differentiation. This step serves to expand the pool of pancreatic progenitors before differentiation is initiated and notch inhibition results in Ngn3 expression, and further differentiation towards the 
endocrine fate (Apelqvist et al. 1999, Jensen et al. 2000). Consistent with this, mouse embryos overexpressing Ngn3 or lacking the CSL or Delta-like1 mediators or both Hes 1 alleles show an accelerated endocrine differentiation coupled with pancreatic hypoplasia (Apelqvist et al. 1999, Jensen et al. 2000). Conversely, sustained notch activity strongly represses endocrine differentiation (Hald et al. 2003, Murtaugh et al. 2003).

Modulators of the Notch signaling pathway Given its role in pancreas development, repressing the notch pathway in vitro would be expected to enhance differentiation towards a $\beta$-cell fate. Notch repressors could be employed after Hedgehog downregulation and subsequent $P d x 1$ activation, in accordance with the known developmental process in vivo. However, in three studies employing hESCs that incorporated notch inhibition in their differentiation protocols (D'Amour et al. 2006, Phillips et al. 2007, Cho et al. 2008), this inhibition had only a slight impact on promoting endocrine differentiation. Both of these studies used $\mathrm{N}-[\mathrm{N}-$ (3,5-difluorophenacetyl)-L-alanyl]-S-phenylglycine $t$-butyl ester (DAPT), which was added after $P d x 1$ activation. DAPT belongs to a class of compounds called $\gamma$-secretase inhibitors, which, as the name suggests, inhibit notch signaling by preventing activation of the $\gamma$-secretase enzyme which, in turn, blocks NICD release (De Strooper et al. 1999). However, not all $\gamma$-secretase inhibitors specifically affect notch signaling (Lundkvist \& Näslund 2007), and $\gamma$-secretase inhibitors other than DAPT may prove to be more efficient within the context of $\beta$-cell differentiation. The first $\gamma$-secretase inhibitors, including the peptidyl aldehydes MG-132 and MDL-28170, were identified more than a decade ago (Higaki et al. 1995, Kopan et al. 1996). Soon thereafter, a difluoroketone chemical, named MW167 (sometimes referred to as compound 1), was also shown to inhibit $\gamma$-secretase activity (Wolfe et al. 1998). All of these compounds also tested positive for Notch inhibition, either in vivo (Taniguchi et al. 2002) or in vitro (Beck \& Slack 2002). More recent inhibitors that are also known to modulate Notch include a hydroxyethylene peptidomimetic named L-685,458 (Shearman et al. 2000, Sernee et al. 2003) together with its homologous counterpart III-31-C (Li et al. 2000, Esler $e t$ al. 2002), the structurally related compounds D and E (Seiffert et al. 2000, Beher et al. 2001), CBAP (Beher et al. 2001), LY411575 (Dovey et al. 2001, Wong et al. 2004), a dibenzazepine and benzodiazepine (Milano et al. 2004), and a group of epoxides consisting of compounds IL, ILX, and KILX (Piper et al. 2003). The abundance of pharmacological inhibitors of Notch signaling makes this another attractive target for inclusion in future in vitro differentiation protocols, as shown in Fig. 1.

\section{Other modulators}

A number of biologically active compounds that have been used in published endocrine pancreas differentiation protocols cannot be classified under the 'signaling pathway' scheme described in this review, either because they operate through alternative pathways or because their mode of action is uncertain.

Glucagon-like peptide-1 (GLP-1) agonists are thought to promote $\beta$-cell differentiation by acting through several intracellular pathways such as the PI3K, the Hedgehog, the Ras/MAPK, the PKA, and the MEK/ERK pathway to modify the expression of $\beta$-cell transcription factors, including $P d x 1$ (Buteau et al. 1999, Montrose-Rafizadeh et al. 1999, Wang et al. 1999, Zhou et al. 2002, Hui et al. 2009). Recent studies have shown that the GLP-1 peptide and exendin (a potent GLP-1 agonist) can increase the percentage of insulin-expressing cells in mouse $(\mathrm{Ku}$ et al. 2004, Bai et al. 2005), rhesus monkey (Lester et al. 2004), and hESC pancreatic differentiation protocols (Yue et al. 2006, Cho et al. 2008, Hui et al. 2009, Zhang et al. 2009). Insulinlike growth factor 2 also has a known role in $\beta$-cell neogenesis and islet hyperplasia (Petrik et al. 1999, Calderari et al. 2007), and has been used at late stages of the differentiation process in the studies of $\beta$-cell generation from hESCs (Jiang et al. 2007a, Phillips et al. 2007).

Retinoic acid is essential for pancreatic development through the induction of $P d x 1$ expression (Martín et al. 2005, Molotkov et al. 2005) and promoting the generation of $\mathrm{Ngn}^{+}$endocrine progenitors (Öström et al. 2008). Consistent with this, mouse (Micallef et al. 2005, Nakanishi et al. 2007) and human (D'Amour et al. 2006, Jiang et al. 2007b, Shim et al. 2007, Kroon et al. 2008, Johannesson et al. 2009, Zhang et al. 2009) ES cell pancreatic differentiation protocols that incorporate retinoic acid result in the induction of a pancreatic endoderm-like stage.

Some biologically active molecules have been used in ES differentiation protocols with little insight on their mechanisms of action, including indolactam V, nicotinamide, sodium butyrate, and $\beta$-cellulin. Indolactam $V$ is thought to promote differentiation at least, in part, by activating protein kinase C signaling. It was reported to induce expression of $P d x 1$ from mouse and hESCs, and this effect was enhanced in the presence of FGF10 (Chen et al. 2009). Nicotinamide has been reported to promote endocrine differentiation in fetal pancreatic cells (Otonkoski et al. 1993), and has been widely used in in vitro differentiation protocols, either to induce pancreatic differentiation in undifferentiated mESCs (Chen et al. 2008, Vaca et al. 2008) or, more commonly, as a 'maturation factor' in the later stages of mouse (Hori et al. 2002, Vaca et al. 2003, Ku et al. 2004, Naujok et al. 2008a,b) and hESC pancreatic differentiation protocols (Jiang et al. 2007a,b, Cho et al. 2008, Zhang et al. 2009). The precise mode of action of nicotinamide as a morphogen is uncertain, but some of its effects may be mediated through the inhibition of poly(ADP-ribose) synthase which is thought to cause chromatin rearrangements and changes in gene transcription (Otonkoski et al. 1993). $\beta$-Cellulin has been used in a study by Cho et al. (2008), where it was reported to act synergistically with nicotinamide to sustain $P d x 1$ expression and induce 
pancreatic endoderm and islet maturation. Its effects might be due to activation of the epidermal growth factor pathway (Ishiyama et al. 1998).

Finally, a number of biologically active molecules have been shown to influence pancreatic differentiation but have not yet been incorporated into protocols to drive ES cells to an endocrine pancreas phenotype. One example is stauprimide, which has been shown to promote a DE fate in both mouse and hESCs by interacting with the NME2 protein, causing c-Myc downregulation (Zhu et al. 2009). Another example is conophylline, a vinca alkaloid (Umezawa et al. 1994) that has been reported to promote differentiation of murine bone marrow mesenchymal cells (Hisinaga et al. 2008) as well as rat pancreatic acinar carcinoma and pancreatic precursor cells (Umezawa et al. 2003, Ogata et al. 2004, Kitamura et al. 2007) into insulin-producing cells. Its effects are possibly due to induction of the $\mathrm{Ngn} 3$ transcription factor by a p38-dependent mechanism (Umezawa et al. 2003). Another compound, trichostatin A (TSA), which is a hydroxamic acid histone deacetylase inhibitor (HDACi), has been shown to promote differentiation in human endometrial adenocarcinoma cells (Uchida et al. 2005) and promyelocytic leukemia cells (Kitamura et al. 2000), and to induce insulin expression in mouse bone marrow stem cells (Tayaramma et al. 2006). Similarly, other hydroxamic acid HDACis, such as SAHA and pyroxamide, have been shown to induce terminal differentiation in various cell lines including murine erythroleukemia cells (Butler et al. 2001), human endometrial adenocarcinoma cells (Uchida et al. 2005), and human breast cancer cells (Munster et al. 2001). Sodium butyrate has HDACi activity (Rada-Iglesias et al. 2007) which may account for its reported effects to induce DE formation from mouse and hESCs respectively (Goicoa et al. 2006, Jiang et al. 2007b). HDACis have also been reported to upregulate gelsolin, a protein that is a major building block for actin filament formation and which may be associated with the pro-differentiating effects of this class of compound (Mielnicki et al. 1999, Huang \& Pardee 2000, Rombouts et al. 2002, Glaser et al. 2003). Histone deacetylases have been implicated recently in the regulation of expression of key pancreatic transcription factors (Haumaitre et al. 2008), and HDACis, such as TSA and sodium butyrate, have been shown to influence the timing and determination of pancreatic cell fate (Haumaitre et al. 2008), suggesting that this class of compounds may be useful in in vitro differentiation protocols.

\section{Summary and conclusions}

A number of recent studies have demonstrated that recapitulating in vitro the signals controlling the development of the endocrine pancreas in vivo offers a promising strategy for generating insulin-expressing $\beta$-cells from pluripotent ES cells. However, current protocols are not yet optimized for a number of reasons, including the pleiotropic effects induced by individual morphogens, the complexity of the signaling pathways involved, and the likelihood of crosstalk between pathways. We suggest that the establishment of efficient and reproducible protocols will be facilitated by focusing on the intracellular signaling pathways that regulate and direct the developmental transitions. Figure 1 shows a proposed differentiation protocol based on known developmental processes and on currently available pharmacological modulators of the signaling systems. Initially, ES cells can be driven to differentiate into mesendoderm by suppressing the PI3K pathway and keeping Nodal and Wnt signaling sufficiently high. DE can then be generated by maintaining suppression of the PI3K pathway while activating the Nodal pathway activation. Thereafter, developmental evidence is in favor of suppressing the Wnt pathway for generating posterior foregut endoderm, followed by repression of Hedgehog signaling to allow for specification of the pancreatic domain, while inhibiting Notch signaling to promote further differentiation towards the endocrine fate. Finally, suppressing PI3K and activating Hedgehog signaling might further enhance the differentiation towards the much desired functionally mature $\beta$-cells.

\section{Declaration of interest}

Neither author has any conflict of interest concerning the impartiality of this review article.

\section{Funding}

The generation of this review article did not receive any grant support from any funding agency in the public, commercial, or not-for-profit sector.

\section{References}

Almeida M, Han L, Bellido T, Manolagas SC \& Kousteni S 2005 Wnt proteins prevent apoptosis of both uncommitted osteoblast progenitors and differentiated osteoblasts by beta-catenin-dependent and -independent signaling cascades involving Src/ERK and phosphatidylinositol 3-kinase/AKT. Journal of Biological Chemistry $28041342-41351$.

Apelqvist E, Ahlgren U \& Edlund H 1997 Sonic hedgehog directs specialised mesoderm differentiation in the intestine and pancreas. Current Biology 7 801-804.

Apelqvist A, Li H, Sommer L, Beatus P, Anderson DJ, Honjo T, de Angelis MH, Lendahl U \& Edlund H 1999 Notch signalling controls pancreatic cell differentiation. Nature 400 877-881.

Bai L, Meredith G \& Tuch BE 2005 Glucagon-like peptide-1 enhances production of insulin in insulin-producing cells derived from mouse embryonic stem cells. Journal of Endocrinology 186 343-352.

Bakre MM, Hoi A, Mong JC, Koh YY, Wong KY \& Stanton LW 2007 Generation of multipotential mesendodermal progenitors from mouse embryonic stem cells via sustained Wnt pathway activation. Journal of Biological Chemistry 282 31703-31712.

Barnett SF, Defeo-Jones D, Fu S, Hancock PJ, Haskell KM, Jones RE, Kahana JA, Kral AM, Leander K, Lee LL et al. 2005 Identification and characterization of pleckstrin-homology-domain-dependent and isoenzyme-specific Akt inhibitors. Biochemical Journal 385 399-408. 
Beck CW \& Slack JMW 2002 Notch is required for outgrowth of the Xenopus tail bud. International Journal of Developmental Biology 46 255-258.

Beher D, Wrigley JDJ, Nadin A, Evin G, Masters CL, Harrison T, Castro JL \& Shearman MS 2001 Pharmacological knock-down of the presenilin 1 heterodimer by a novel gamma-secretase inhibitor: implications for presenilin biology. Journal of Biological Chemistry 276 45394-45402.

Bhat R, Xue Y, Berg S, Hellberg S, Ormö M, Nilsson Y, Radesäter AC, Jerning E, Markgren PO, Borgegård T et al. 2003 Structural insights and biological effects of glycogen synthase kinase 3-specific inhibitor AR-A014418. Journal of Biological Chemistry 278 45937-45945.

Blyszczuk P \& Wobus AM 2007 In vitro differentiation of embryonic stem cells into the pancreatic lineage. Methods in Molecular Biology 330 373-385.

Blyszczuk P, Czyz J, Kania G, Wagner M, Roll U, St-Onge L \& Wobus AM 2003 Expression of Pax4 in embryonic stem cells promotes differentiation of nestin-positive progenitor and insulin-producing cells. PNAS 100 998-1003.

Bodine PVN, Stauffer B, Ponce-de-Leon H, Bhat RA, Mangine A, SeestallerWehr LM, Moran RA, Billiard J, Fukayama S, Komm BS et al. 2009 A small molecule inhibitor of the Wnt antagonist secreted frizzled-related protein-1 stimulates bone formation. Bone 44 1063-1068.

Borowiak M, Maehr R, Chen S, Chen AE, Tang W, Fox JL, Schreiber SL \& Melton DA 2009 Small molecules efficiently direct endodermal differentiation of mouse and human embryonic stem cells. Cell Stem Cell 4 348-358.

Bray SJ 2006 Notch signalling: a simple pathway becomes complex. Nature Reviews. Molecular Cell Biology 7 678-689.

Buteau J, Roduit R, Susini S \& Prentki M 1999 Glucagon-like peptide-1 promotes DNA synthesis, activates phosphatidylinositol 3-kinase and increases transcription factor pancreatic and duodenal homeobox gene 1 (PDX-1) DNA binding activity in beta (INS-1)-cells. Diabetologia 42 856-864.

Butler LM, Webb Y, Agus DB, Higgins B, Tolentino TR, Kutko MC, LaQuaglia MP, Drobnjak M, Cordon-Cardo C, Scher HI et al. 2001 Inhibition of transformed cell growth and induction of cellular differentiation by pyroxamide, an inhibitor of histone deacetylase. Clinical Cancer Research 7 962-970.

Calderari S, Gangnerau MN, Thibault M, Meile MJ, Kassis N, Alvarez C, Portha B \& Serradas P 2007 Defective IGF2 and IGF1R protein production in embryonic pancreas precedes beta cell mass anomaly in the GotoKakizaki rat model of type 2 diabetes. Diabetologia 50 1463-1471.

Chen JK, Taipale J, Young KE, Maiti T \& Beachy PA 2002 Small molecule modulation of Smoothened activity. PNAS 99 14071-14076.

Chen YG, Wang Q, Lin SL, Chang CD, Chung J \& Ying SY 2006 Activin signaling and its role in regulation of cell proliferation, apoptosis, and carcinogenesis. Experimental Biology and Medicine 231 534-544.

Chen C, Zhang Y, Sheng X, Huang C \& Zang YQ 2008 Differentiation of embryonic stem cells towards pancreatic progenitor cells and their transplantation into streptozotocin-induced diabetic mice. Cell Biology International 32 456-461.

Chen S, Borowiak M, Fox JL, Maehr R, Osafune K, Davidow L, Lam K, Peng LF, Schreiber SL, Rubin LL et al. 2009 A small molecule that directs differentiation of human ESCs into the pancreatic lineage. Nature Chemical Biology 5 258-265.

Cho YM, Lim JM, Yoo DH, Kim JH, Chung SS, Park SG, Kim TH, Oh SK, Choi YM, Moon SY et al. 2008 Betacellulin and nicotinamide sustain PDX1 expression and induce pancreatic beta-cell differentiation in human embryonic stem cells. Biochemical and Biophysical Research Communications 366 129-134.

Chuang PT \& McMahon AP 1999 Vertebrate Hedgehog signalling modulated by induction of a Hedgehog-binding protein. Nature 397 617-621.

Coghlan MP, Culbert AA, Cross DA, Corcoran SL, Yates JW, Pearce NJ, Rausch OL, Murphy GJ, Carter PS, Roxbee Cox L et al. 2000 Selective small molecule inhibitors of glycogen synthase kinase- 3 modulate glycogen metabolism and gene transcription. Chemistry \& Biology 7 793-803.

Cooper MK, Porter JA, Young KE \& Beachy PA 1998 Teratogen-mediated inhibition of target tissue response to Shh signaling. Science 280 1603-1607.
D'Amour KA, Agulnick AD, Eliazer S, Kelly OG, Kroon E \& Baetge EE 2005 Efficient differentiation of human embryonic stem cells to definitive endoderm. Nature Biotechnology 23 1534-1541.

D'Amour KA, Bang AG, Eliazer S, Kelly OG, Agulnick AD, Smart NG, Moorman MA, Kroon E, Carpenter MK \& Baetge EE 2006 Production of pancreatic hormone-expressing endocrine cells from human embryonic stem cells. Nature Biotechnology 24 1392-1401.

De Strooper B, Annaert W, Cupers P, Saftig P, Craessaerts K, Mumm JS, Schroeter EH, Schrijvers V, Wolfe MS, Ray WJ et al. 1999 A presenilin-1dependent [gamma]-secretase-like protease mediates release of Notch intracellular domain. Nature 398 518-522.

Dovey HF, John V, Anderson JP, Chen LZ, de Saint Andrieu P, Fang LY, Freedman SB, Folmer B, Goldbach E, Holsztynska EJ et al. 2001 Functional gamma-secretase inhibitors reduce beta-amyloid peptide levels in brain. Journal of Neurochemistry 76 173-181.

Dyer MA, Farrington SM, Mohn D, Munday JR \& Baron MH 2001 Indian Hedgehog activates hematopoiesis and vasculogenesis and can respecify prospective neurectodermal cell fate in the mouse embryo. Development 128 1717-1730.

Echelard Y, Epstein DJ, St-Jacques B, Shen L, Mohler J, McMahon JA \& McMahon AP 1993 Sonic Hedgehog, a member of a family of putative signaling molecules, is implicated in the regulation of CNS polarity. Cell $\mathbf{7 5}$ 1417-1430.

Eiselein L, Schwartz HJ \& Rutledge JC 2004 The challenge of type 1 diabetes mellitus. ILAR 45 231-236.

Emami KH, Nguyen C, Ma H, Kim DH, Jeong KW, Eguchi M, Moon RT, Teo JL, Oh SW, Kim HY et al. 2004 A small molecule inhibitor of betacatenin/CREB-binding protein transcription. PNAS 101 12682-12687.

Esler WP, Kimberly WT, Ostaszewski BL, Ye W, Diehl TS, Selkoe DJ \& Wolfe MS 2002 Activity-dependent isolation of the presenilin- gamma -secretase complex reveals nicastrin and a gamma substrate. PNAS 99 $2720-2725$.

Evans MJ \& Kaufman MH 1981 Establishment in culture of pluripotential cells from mouse embryos. Nature 292 154-156.

Frandsen U, Porneki AD, Floridon C, Abdallah BM \& Kassem M 2007 Activin B mediated induction of $P d x 1$ in human embryonic stem cell derived embryoid bodies. Biochemical and Biophysical Research Communications 362 568-574.

Frank-Kamenetsky M, Zhang X, Bottega S, Guicherit O, Wichterle H, Dudek H, Bumcrot D, Wang F, Jones S, Shulok J et al. 2002 Small-molecule modulators of Hedgehog signaling: identification and characterization of Smoothened agonists and antagonists. Journal of Biology 110.

Fujii N, You L, Xu Z, Uematsu K, Shan J, He B, Mikami I, Edmondson LR, Neale G, Zheng J et al. 2007 An antagonist of dishevelled protein-protein interaction suppresses beta-catenin-dependent tumor cell growth. Cancer Research 67 573-579.

Fukumoto S, Hsieh CM, Maemura K, Layne MD, Yet SF, Lee KH, Matsui T, Rosenzweig A, Taylor WG, Rubin JS et al. 2001 Akt participation in the Wnt signaling pathway through dishevelled. Journal of Biological Chemistry 276 17479-17483.

van Gijn ME, Daemen MJAP, Smits JFM \& Blankesteijn WM 2002 The wntfrizzled cascade in cardiovascular disease. Cardiovascular Research 55 16-24.

Glaser KB, Staver MJ, Waring JF, Stender J, Ulrich RG \& Davidsen SK 2003 Gene expression profiling of multiple histone deacetylase (HDAC) inhibitors: defining a common gene set produced by HDAC inhibition in T24 and MDA carcinoma cell lines. Molecular Cancer Therapeutics 2 151-163.

Goicoa S, Alvarez S, Ricordi C, Inverardi L \& Dominguez-Bendala J 2006 Sodium butyrate activates genes of early pancreatic development in embryonic stem cells. Cloning and Stem Cells 8 140-149.

Gradwohl G, Dierich A, LeMeur M \& Guillemot F 2000 Neurogenin3 is required for the development of the four endocrine cell lineages of the pancreas. PNAS 97 1607-1611.

Gregorieff A, Grosschedl R \& Clevers H 2004 Hindgut defects and transformation of the gastro-intestinal tract in Tcf4-/ - /Tcf1 -/ embryos. EMBO Journal 23 1825-1833. 
Gu G, Dubauskaite J \& Melton DA 2002 Direct evidence for the pancreatic lineage: Ngn3 + cells are islet progenitors and are distinct from duct progenitors. Development 129 2447-2457.

Hald J, Hjorth JP, German MS, Madsen OD, Serup P \& Jensen J 2003 Activated Notch1 prevents differentiation of pancreatic acinar cells and attenuate endocrine development. Developmental Biology 260 426-437.

Hansson M, Tonning A, Frandsen U, Petri A, Rajagopal J, Englund MCO, Heller RS, Hakansson J, Fleckner J, Skold HN et al. 2004 Artifactual insulin release from differentiated embryonic stem cells. Diabetes 53 2603-2609.

Haumaitre C, Lenoir O \& Scharfmann R 2008 Histone deacetylase inhibitors modify pancreatic cell fate determination and amplify endocrine progenitors. Molecular Cell Biology 28 6373-6383.

He XC, Yin T, Grindley JC, Tian Q, Sato T, Tao WA, Dirisina R, PorterWestpfahl KS, Hembree M, Johnson T et al. 2007 PTEN-deficient intestinal stem cells initiate intestinal polyposis. Nature Genetics 39 189-198.

Hebrok M, Kim SK \& Melton DA 1998 Notochord repression of endodermal Sonic Hedgehog permits pancreas development. Genes and Development 12 1705-1713.

Hebrok M, Kim SK, St Jacques B, McMahon AP \& Melton DA 2000 Regulation of pancreas development by Hedgehog signaling. Development 127 4905-4913.

Heller RS, Dichmann DS, Jensen J, Miller C, Wong G, Madsen OD \& Serup P 2002 Expression patterns of Wnts, Frizzleds, sFRPs, and misexpression in transgenic mice suggesting a role for Wnts in pancreas and foregut pattern formation. Developmental Dynamics 225 260-270.

Higaki J, Quon D, Zhong Z \& Cordell B 1995 Inhibition of beta-amyloid formation identifies proteolytic precursors and subcellular site of catabolism. Neuron 14 651-659.

Hisinaga E, Park KY, Yamada S, Hashimoto H, Takeuchi T, Mori M, Seno M, Umezawa K, Takei I \& Kojima I 2008 A simple method to induce differentiation of murine bone marrow mesenchymal cells to insulinproducing cells using conophylline and betacellulin-delta4. Endocrine Journal 55 535-543.

Hori Y, Rulifson IC, Tsai BC, Heit JJ, Cahoy JD \& Kim SK 2002 Growth inhibitors promote differentiation of insulin-producing tissue from embryonic stem cells. PNAS 99 16105-16110.

Hori Y, Gu X, Xie X \& Kim SK 2005 Differentiation of insulin-producing cells from human neural progenitor cells. PLoS Medicine 2 e103.

Huang L \& Pardee AB 2000 Suberoylanilide hydroxamic acid as a potential therapeutic agent for human breast cancer treatment. Molecular Medicine 6 849-866.

Hui H, Tang Y, Zhu L, Khoury N, Hui Z, Wang K, Perfetti R \& Go V 2009 Glucagon like peptide-1-directed human embryonic stem cells differentiation into insulin-producing cells via Hedgehog, cAMP, and PI3K pathways. Pancreas 39 315-322.

Incardona JP, Gaffield W, Lange Y, Cooney A, Pentchev PG, Liu S, Watson JA, Kapur RP \& Roelink H 2000 Cyclopamine inhibition of Sonic Hedgehog signal transduction is not mediated through effects on cholesterol transport. Developmental Biology 224 440-452.

Ishiyama N, Kanzaki M, Seno M, Yamada H, Kobayashi I \& Kojima I 1998 Studies on the betacellulin receptor in pancreatic AR42J cells. Diabetologia 41 623-628.

Itäranta P, Chi L, SeppSnen T, Niku M, Tuukkanen J, Peltoketo H \& Vainio S 2006 Wnt-4 signaling is involved in the control of smooth muscle cell fate via Bmp-4 in the medullary stroma of the developing kidney. Developmental Biology 293 473-483.

Ito K, Caramori G \& Adcock IM 2007 Therapeutic potential of phosphatidylinositol 3-kinase inhibitors in inflammatory respiratory disease. Journal of Pharmacology and Experimental Therapeutics 321 1-8.

Jensen J, Pedersen EE, Galante P, Hald J, Heller RS, Ishibashi M, Kageyama R, Guillemot F, Serup P \& Madsen OD 2000 Control of endodermal endocrine development by Hes-1. Nature Genetics 24 36-44.

Jiang J, Au M, Lu K, Eshpeter A, Korbutt G, Fisk G \& Majumdar AS 2007a Generation of insulin-producing islet-like clusters from human embryonic stem cells. Stem Cells 25 1940-1953.
Jiang W, Shi Y, Zhao D, Chen S, Yong J, Zhang J, Qing T, Sun X, Zhang P, Ding $M$ et al. 2007b In vitro derivation of functional insulin-producing cells from human embryonic stem cells. Cell Research 17 333-344.

Johannesson M, Ståhlberg A, Ameri J, Sand FW, Norrman K \& Semb H 2009 FGF4 and retinoic acid direct differentiation of hESCs into PDX1expressing foregut endoderm in a time- and concentration-dependent manner. PLOS ONE 4 e 4794.

Kawahira H, Scheel DW, Smith SB, German MS \& Hebrok M 2005 Hedgehog signaling regulates expansion of pancreatic epithelial cells. Developmental Biology 280 111-121.

Kawano Y \& Kypta R 2003 Secreted antagonists of the Wnt signalling pathway. Journal of Cell Science 116 2627-2634.

Kim SK \& Melton DA 1998 Pancreas development is promoted by cyclopamine, a Hedgehog signaling inhibitor. PNAS 95 13036-13041.

Kispert A, Vainio S \& McMahon AP 1998 Wnt-4 is a mesenchymal signal for epithelial transformation of metanephric mesenchyme in the developing kidney. Development 125 4225-4234.

Kitamura K, Hoshi S, Koike M, Kiyoi H, Saito H \& Naoe T 2000 Histone deacetylase inhibitor but not arsenic trioxide differentiates acute promyelocytic leukaemia cells with $\mathrm{t}(11 ; 17)$ in combination with all-trans retinoic acid. British Journal of Haematology 108 696-702.

Kitamura RI, Ogata T, Tanaka Y, Motoyoshi K, Seno M, Takei I, Umezawa K \& Kojima I 2007 Conophylline and betacellulin-delta4: an effective combination of differentiation factors for pancreatic beta cells. Endocrine Journal 54 255-264.

Kopan R, Schroeter EH, Weintraub H \& Nye JS 1996 Signal transduction by activated mNotch: importance of proteolytic processing and its regulation by the extracellular domain. PNAS 93 1683-1688.

Kroon E, Martinson LA, Kadoya K, Bang AG, Kelly OG, Eliazer S, Young H, Richardson M, Smart NG, Cunningham J et al. 2008 Pancreatic endoderm derived from human embryonic stem cells generates glucose-responsive insulin-secreting cells in vivo. Nature Biotechnology 26 443-452.

Ku HT, Zhang N, Kubo A, O'Connor R, Mao M, Keller G \& Bromberg JS 2004 Committing embryonic stem cells to early endocrine pancreas in vitro. Stem Cells 22 1205-1217.

Kubo A, Shinozaki K, Shannon JM, Kouskoff V, Kennedy M, Woo S, Fehling HJ \& Keller G 2004 Development of definitive endoderm from embryonic stem cells in culture. Development 131 651-1662.

Kuo GH, Prouty C, DeAngelis A, Shen L, O’Neill DJ, Shah C, Connolly PJ, Murray WV, Conway BR, Cheung P et al. 2003 Synthesis and discovery of macrocyclic polyoxygenated bis-7-azaindolylmaleimides as a novel series of potent and highly selective glycogen synthase kinase-3beta inhibitors. Journal of Medicinal Chemistry 46 4021-4031.

Leclerc S, Garnier M, Hoessel R, Marko D, Bibb JA, Snyder GL, Greengard P, Biernat J, Wu YZ, Mandelkow EM et al. 2001 Indirubins inhibit glycogen synthase kinase-3beta and CDK5/P25, two protein kinases involved in abnormal tau phosphorylation in Alzheimer's disease. A property common to most cyclin-dependent kinase inhibitors? Journal of Biological Chemistry 276 251-260.

Lee J, Wu X, di Magliano MP, Peters EC, Wang Y, Hong J, Hebrok M, Ding S, Cho CY \& Schultz PG 2007 A small-molecule antagonist of the hedgehog signaling pathway. Chembiochem 8 1916-1919.

Lepourcelet M, Chen YN, France DS, Wang H, Crews P, Petersen F, Bruseo C, Wood AW \& Shivdasani RA 2004 Small-molecule antagonists of the oncogenic Tcf/[beta]-catenin protein complex. Cancer Cell $\mathbf{5}$ 91-102.

Lester L, Kuo HC, Andrews L, Nauert B \& Wolf D 2004 Directed differentiation of rhesus monkey ES cells into pancreatic cell phenotypes. Reproductive Biology and Endocrinology 242.

Li YM, Xu M, Lai MT, Huang Q, Castro JL, Muzio-Mower J, Harrison T, Lellis C, Nadin A, Neduvelil JG et al. 2000 Photoactivated gamma-secretase inhibitors directed to the active site covalently label presenilin 1. Nature $\mathbf{4 0 5}$ 689-694.

Liu J, Wu X, Mitchell B, Kintner C, Ding S \& Schultz PG 2005 A smallmolecule agonist of the Wnt signaling pathway. Angewandte Chemie (International ed. in English) 44 1987-1990.

Logan CY \& Nusse R 2004 The Wnt signaling pathway in development and disease. Annual Review of Cell and Developmental Biology 20781. 
Lumelsky N, Blondel O, Laeng P, Velasco I, Ravin R \& McKay R 2001 Differentiation of embryonic stem cells to insulin-secreting structures similar to pancreatic islets. Science 292 1389-1394.

Lundkvist J \& Näslund J 2007 Gamma-secretase: a complex target for Alzheimer's disease. Current Opinion in Pharmacology 7 112-118.

Mandrup-Poulsen T 2003 Beta cell death and protection. Annals of the New York Academy of Sciences 1005 32-42.

Marigo V, Roberts DJ, Lee SMK, Tsukurov O, Levi T, Gastier JM, Epstein DJ, Gilbert DJ, Copeland NG, Seidman CE et al. 1995 Cloning, expression, and chromosomal location of SHH and IHH: two human homologues of the Drosophila segment polarity gene hedgehog. Genomics 28 44-51.

Marikawa Y, Tamashiro DAA, Fujita TC \& Alarcon VB 2008 Regulation of mesendoderm formation and axial elongation by Wnt signaling in mouse embryonal carcinoma cells. Biology of Reproduction $\mathbf{7 8} 331$.

Martín M, Gallego-Llamas J, Ribes V, Kedinger M, Niederreither K, Chambon P, Dollé P \& Gradwohl G 2005 Dorsal pancreas agenesis in retinoic acid-deficient Raldh2 mutant mice. Developmental Biology 284 399-411.

Massagué J 1998 TGF-beta signal transduction. Annual Review of Biochemistry 67753.

Massagué J \& Chen YG 2000 Controlling TGF-beta signaling. Genes and Development 14 627-644.

McLean AB, D'Amour KA, Jones KL, Krishnamoorthy M, Kulik MJ, Reynolds DM, Sheppard AM, Liu H, Xu Y, Baetge EE et al. 2007 Activin A efficiently specifies definitive endoderm from human embryonic stem cells only when phosphatidylinositol 3-kinase signaling is suppressed. Stem Cells 25 29-38.

McLin VA, Rankin SA \& Zorn AM 2007 Repression of Wnt/beta-catenin signaling in the anterior endoderm is essential for liver and pancreas development. Development 134 2207-2217.

McMahon AP \& Bradley A 1990 The Wnt-1 (int-1) proto-oncogene is required for development of a large region of the mouse brain. Cell $\mathbf{6 2}$ 1073-1085

McMahon AP, Joyner AL, Bradley A \& McMahon JA 1992 The midbrainhindbrain phenotype of Wnt-1 - /Wnt-1 - mice results from stepwise deletion of engrailed-expressing cells by 9.5 days postcoitum. Cell 69 581-595.

Meijer L, Skaltsounis AL, Magiatis P, Polychronopoulos P, Knockaert M, Leost M, Ryan XP, Vonica CA, Brivanlou A, Dajani R et al. 2003 GSK-3selective inhibitors derived from tyrian purple indirubins. Chemistry $\mathcal{E}$ Biology 10 1255-1266.

Merrill BJ, Pasolli HA, Polak L, Rendl M, Garcia-Garcia MJ, Anderson KV \& Fuchs E 2004 Tcf3: a transcriptional regulator of axis induction in the early embryo. Development 131 263-274.

Mfopou JK, Willems E, Leyns L \& Bouwens L 2005 Expression of regulatory genes for pancreas development during murine embryonic stem cell differentiation. International Journal of Developmental Biology 49 915-922.

Mfopou JK, De Groote V, Xu X, Heimberg H \& Bouwens L 2007 Sonic Hedgehog and other soluble factors from differentiating embryoid bodies inhibit pancreas development. Stem Cells 25 1156-1165.

Micallef SJ, Janes ME, Knezevic K, Davis RP, Elefanty AG \& Stanley EG 2005 Retinoic acid induces Pdx1-positive endoderm in differentiating mouse embryonic stem cells. Diabetes 54 301-305.

Mielnicki LM, Ying AM, Head KL, Asch HL \& Asch B 1999 Epigenetic regulation of gelsolin expression in human breast cancer cells. Experimental Cell Research 249 161-176.

Milano J, McKay J, Dagenais C, Foster-Brown L, Pognan F, Gadient R, Jacobs RT, Zacco A, Greenberg B \& Ciaccio PJ 2004 Modulation of Notch processing by gamma-secretase inhibitors causes intestinal goblet cell metaplasia and induction of genes known to specify gut secretory lineage differentiation. Toxicological Sciences 82 341-358.

Miyazaki S, Yamato E \& Miyazaki JI 2004 Regulated expression of pdx-1 promotes in vitro differentiation of insulin-producing cells from embryonic stem cells. Diabetes 53 1030-1037.

Molotkov A, Molotkova N \& Duester G 2005 Retinoic acid generated by Raldh2 in mesoderm is required for mouse dorsal endodermal pancreas development. Developmental Dynamics 232 950-957.
Montrose-Rafizadeh C, Avdonin P, Garant MJ, Rodgers BD, Kole S, Yang H, Levine MA, Schwindinger W \& Bernier M 1999 Pancreatic glucagon-like peptide-1 receptor couples to multiple $G$ proteins and activates mitogenactivated protein kinase pathways in Chinese hamster ovary cells. Endocrinology 140 1132-1140.

Munster PN, Troso-Sandoval T, Rosen N, Rifkind R, Marks PA \& Richon VM 2001 The histone deacetylase inhibitor suberoylanilide hydroxamic acid induces differentiation of human breast cancer cells. Cancer Research $\mathbf{6 1}$ 8492-8497.

Murtaugh LC, Stanger BZ, Kwan KM \& Melton DA 2003 Notch signaling controls multiple steps of pancreatic differentiation. PNAS 100 14920-14925.

Nakanishi M, Hamazaki TS, Komazaki S, Okochi H \& Asashima M 2007 Pancreatic tissue formation from murine embryonic stem cells in vitro. Differentiation 75 1-11.

Naujok O, Francini F, Jörns A \& Lenzen S 2008a An efficient experimental strategy for mouse embryonic stem cell differentiation and separation of a cytokeratin-19-positive population of insulin-producing cells. Cell Proliferation 41 607-624.

Naujok O, Francini F, Picton S, Jörns A, Bailey CJ \& Lenzen S 2008b A new experimental protocol for preferential differentiation of mouse embryonic stem cells into insulin-producing cells. Cell Transplantation 17 1231-1242.

Naylor S, Smalley MJ, Robertson D, Gusterson BA, Edwards PA \& Dale TC 2000 Retroviral expression of Wnt-1 and Wnt-7b produces different effects in mouse mammary epithelium. Journal of Cell Science $\mathbf{1 1 3}$ 2129-2138.

Ng SS, Mahmoudi T, Danenberg E, Bejaoui I, de Lau W, Korswagen HC, Schutte M \& Clevers H 2009 Phosphatidylinositol 3-kinase (PI3K) signaling does not activate the Wnt cascade. Journal of Biological Chemistry 284 35308-35313.

Nusslein-Volhard C \& Wieschaus E 1980 Mutations affecting segment number and polarity in Drosophila. Nature 287 795-801.

Ogata T, Li L, Yamada S, Yamamoto Y, Tanaka Y, Takei I, Umezawa K \& Kojima I 2004 Promotion of beta-cell differentiation by conophylline in fetal and neonatal rat pancreas. Diabetes 53 2596-2602.

Onkamo P, Väänänen S, Karvonen M \& Tuomilehto J 1999 Worldwide increase in incidence of type I diabetes - the analysis of the data on published incidence trends. Diabetologia 42 1395-1403.

Öström M, Loffler KA, Edfalk S, Selander L, Dahl U, Ricordi C, Jeon J, Correa-Medina M, Diez J \& Edlund H 2008 Retinoic acid promotes the generation of pancreatic endocrine progenitor cells and their further differentiation into beta-cells. PLoS ONE 3 e2841.

Otonkoski T, Beattie GM, Mally MI, Ricordi C \& Hayek A 1993 Nicotinamide is a potent inducer of endocrine differentiation in cultured human fetal pancreatic cells. Journal of Clinical Investigation 92 1459-1466.

Paek HJ, Morgan JR \& Lysaght MJ 2005 Sequestration and synthesis: the source of insulin in cell clusters differentiated from murine embryonic stem cells. Stem Cells 23 862-867.

Paling NRD, Wheadon H, Bone HK \& Welham MJ 2004 Regulation of embryonic stem cell self-renewal by phosphoinositide 3-kinase-dependent signaling. Journal of Biological Chemistry 279 48063-48070.

Peat AJ, Boucheron JA, Dickerson SH, Garrido D, Mills W, Peckham J, Preugschat F, Smalley T, Schweiker SL, Wilson JR et al. 2004a Novel pyrazolopyrimidine derivatives as GSK-3 inhibitors. Bioorganic \& Medicinal Chemistry Letters 14 2121-2125.

Peat AJ, Garrido D, Boucheron JA, Schweiker SL, Dickerson SH, Wilson JR, Wang TY \& Thomson SA $2004 b$ Novel GSK-3 inhibitors with improved cellular activity. Bioorganic \& Medicinal Chemistry Letters 14 2127-2130.

Peifer M \& Polakis P 2000 Wnt signaling in oncogenesis and embryogenesis a look outside the nucleus. Science 287 1606-1609.

Petrik J, Pell JM, Arany E, McDonald TJ, Dean WL, Reik W \& Hill DJ 1999 Overexpression of insulin-like growth factor-II in transgenic mice is associated with pancreatic islet cell hyperplasia. Endocrinology 140 2353-2363.

Phillips BW, Hentze H, Rust WL, Chen QP, Chipperfield H, Tan EK, Abraham S, Sadasivam A, Soong PL, Wang ST et al. 2007 Directed differentiation of human embryonic stem cells into the pancreatic endocrine lineage. Stem Cells and Development 16 561-578. 
Piper SC, Amtul Z, Galipanes-Garcia L, Howard VG, Ziani-Cherif C, McLendon C, Rochette MJ, Fauq A, Golde TE \& Paul Murphy M 2003 Peptide-based, irreversible inhibitors of gamma-secretase activity. Biochemical and Biophysical Research Communications 305 529-533.

Ptasznik A, Beattie GM, Mally MI, Cirulli V, Lopez A \& Hayek A 1997 Phosphatidylinositol 3-kinase is a negative regulator of cellular differentiation. Journal of Cell Biology 137 1127-1136.

Rada-Iglesias A, Enroth S, Ameur A, Koch CM, Clelland GK, RespuelaAlonso P, Wilcox S, Dovey OM, Ellis PD, Langford CF et al. 2007 Butyrate mediates decrease of histone acetylation centered on transcription start sites and down-regulation of associated genes. Genome Research 17 708-719.

Rajagopal J, Anderson WJ, Kume S, Martinez OI \& Melton DA 2003 Insulin staining of ES cell progeny from insulin uptake. Science 299363.

Ring DB, Johnson KW, Henriksen EJ, Nuss JM, Goff D, Kinnick TR, Ma ST, Reeder JW, Samuels I, Slabiak T et al. 2003 Selective glycogen synthase kinase 3 inhibitors potentiate insulin activation of glucose transport and utilization in vitro and in vivo. Diabetes 52 588-595.

Rombouts K, Knittel T, Machesky L, Braet F, Wielant A, Hellemans K, De Bleser P, Gelman I, Ramadori G \& Geerts A 2002 Actin filament formation, reorganization and migration are impaired in hepatic stellate cells under influence of trichostatin A, a histone deacetylase inhibitor. Journal of Hepatology 37 788-796.

Ryan EA, Paty BW, Senior PA, Bigam D, Alfadhli E, Kneteman NM, Lakey JRT \& Shapiro AMJ 2005 Five-year follow-up after clinical islet transplantation. Diabetes 54 2060-2069.

Sanvito F, Herrera PL, Huarte J, Nichols A, Montesano R, Orci L \& Vassalli JD 1994 TGF-beta 1 influences the relative development of the exocrine and endocrine pancreas in vitro. Development 120 3451-3462.

Schier AF \& Shen MM 2000 Nodal signalling in vertebrate development. Nature 403 385-389.

Schroeder IS, Rolletschek A, Blyszczuk P, Kania G \& Wobus AM 2006 Differentiation of mouse embryonic stem cells to insulin-producing cells. Nature Protocols 1 495-507.

Seaberg RM, Smukler SR, Kieffer TJ, Enikolopov G, Asghar Z, Wheeler MB, Korbutt G \& van der Kooy D 2004 Clonal identification of multipotent precursors from adult mouse pancreas that generate neural and pancreatic lineages. Nature Biotechnology 22 1115-1124.

Segev H, Fishman B, Ziskind A, Shulman M \& Itskovitz-Eldor J 2004 Differentiation of human embryonic stem cells into insulin-producing clusters. Stem Cells 22 265-274.

Seiffert D, Bradley JD, Rominger CM, Rominger DH, Yang F, Meredith JE Jr, Wang Q, Roach AH, Thompson LA, Spitz SM et al. 2000 Presenilin-1 and -2 are molecular targets for gamma-secretase inhibitors. Journal of Biological Chemistry 275 34086-34091.

Serafimidis I, Rakatzi I, Episkopou V, Gouti M \& Gavalas A 2008 Novel effectors of directed and Ngn3-mediated differentiation of mouse embryonic stem cells into endocrine pancreas progenitors. Stem Cells $\mathbf{2 6}$ 3-16.

Sernee FM, Evin G, Culvenor JG, Villadangos JA, Beyreuther K, Masters CL \& Cappai R 2003 Selecting cells with different Alzheimer's disease gammasecretase activity using FACS. Differential effect on presenilin exon 9 gamma- and epsilon-cleavage. European Journal of Biochemistry 270 495-506.

Shan J, Shi D-L, Wang J \& Zheng J 2005 Identification of a specific inhibitor of the dishevelled PDZ domain. Biochemistry 44 15495-15503.

Shapiro AMJ, Lakey JRT, Ryan EA, Korbutt GS, Toth E, Warnock GL, Kneteman NM \& Rajotte RV 2000 Islet transplantation in seven patients with type 1 diabetes mellitus using a glucocorticoid-free immunosuppressive regimen. New England Journal of Medicine 343 230-238.

Shearman MS, Beher D, Clarke EE, Lewis HD, Harrison T, Hunt P, Nadin A, Smith AL, Stevenson G \& Castro JL 2000 L-685,458, an aspartyl protease transition state mimic, is a potent inhibitor of amyloid beta-protein precursor gamma-secretase activity. Biochemistry 39 8698-8704.

Shi Y, Hou L, Tang F, Jiang W, Wang P, Ding M \& Deng H 2005 Inducing embryonic stem cells to differentiate into pancreatic beta cells by a novel three-step approach with activin A and all-trans retinoic acid. Stem Cells $23656-662$
Shim JH, Kim SE, Woo DH, Kim SK, Oh CH, McKay R \& Kim JH 2007 Directed differentiation of human embryonic stem cells towards a pancreatic cell fate. Diabetologia 50 1228-1238.

Shiraki N, Lai CJ, Hishikari Y \& Kume S 2005 TGF-beta signaling potentiates differentiation of embryonic stem cells to Pdx1 expressing endodermal cells. Genes to Cells 10 503-516.

Shiroi A, Ueda S, Ouji Y, Moriya K, Sugie Y, Fukui H, Ishizaka S \& Yoshikawa M 2005 Differentiation of embryonic stem cells into insulinproducing cells promoted by Nkx2-2 gene transfer. World Journal of Gastroenterology 11 4161-4166.

Sipione S, Eshpeter A, Lyon JG, Korbutt GS \& Bleackley RC 2004 Insulin expressing cells from differentiated embryonic stem cells are not beta cells. Diabetologia 47 499-508.

Skoudy A, Rovira M, Savatier P, Martin F, León-Quinto T, Soria B \& Real FX 2004 Transforming growth factor (TGF) beta, fibroblast growth factor (FGF) and retinoid signalling pathways promote pancreatic exocrine gene expression in mouse embryonic stem cells. Biochemical Journal 379 749-756.

Soria B, Roche E, Berná G, León-Quinto T, Reig JA \& Martín F 2000 Insulin-secreting cells derived from embryonic stem cells normalize glycemia in streptozotocin-induced diabetic mice. Diabetes 49 157-162.

Stambolic V, Ruel L \& Woodgett JR 1996 Lithium inhibits glycogen synthase kinase-3 activity and mimics wingless signalling in intact cells. Current Biology 6 1664-1669.

Strulovici Y, Leopold PL, O’Connor TP, Pergolizzi RG \& Crystal RG 2007 Human embryonic stem cells and gene therapy. Molecular Therapy $\mathbf{1 5}$ 850-866.

Suzuki A, Nakauchi H \& Taniguchi H 2004 Prospective isolation of multipotent pancreatic progenitors using flow-cytometric cell sorting. Diabetes 53 2143-2152.

Tada S, Era T, Furusawa C, Sakurai H, Nishikawa S, Kinoshita M, Nakao K, Chiba T \& Nishikawa SI 2005 Characterization of mesendoderm: a diverging point of the definitive endoderm and mesoderm in embryonic stem cell differentiation culture. Development 132 4363-4374.

Taipale J, Chen JK, Cooper MK, Wang B, Mann RK, Milenkovic L, Scott MP \& Beachy PA 2000 Effects of oncogenic mutations in Smoothened and Patched can be reversed by cyclopamine. Nature 406 1005-1009.

Taniguchi Y, Karlstrom H, Lundkvist J, Mizutani T, Otaka A, Vestling M, Bernstein A, Donoviel D, Lendahl U \& Honjo T 2002 Notch receptor cleavage depends on but is not directly executed by presenilins. PNAS 99 4014-4019.

Tayaramma T, Ma B, Rohde M \& Mayer H 2006 Chromatin-remodeling factors allow differentiation of bone marrow cells into insulin-producing cells. Stem Cells 24 2858-2867.

Tei E, Mehta S, Tulachan SS, Yew H, Hembree M, Preuett B, Snyder C, Yamataka A, Miyano T \& Gittes G 2005 Synergistic endocrine induction by GLP-1 and TGF-[beta] in the developing pancreas. Pancreas 31 138-141.

Thomas MK, Rastalsky N, Lee JH \& Habener JF 2000 Hedgehog signaling regulation of insulin production by pancreatic beta-cells. Diabetes $\mathbf{4 9}$ 2039-2047.

Thomas MK, Lee JH, Rastalsky N \& Habener JF 2001 Hedgehog signaling regulation of homeodomain protein islet duodenum homeobox-1 expression in pancreatic beta-cells. Endocrinology 142 1033-1040.

Thomson JA, Itskovitz-Eldor J, Shapiro SS, Waknitz MA, Swiergiel JJ, Marshall VS \& Jones JM 1998 Embryonic stem cell lines derived from human blastocysts. Science 282 1145-1147.

Tremblay KD, Hoodless PA, Bikoff EK \& Robertson EJ 2000 Formation of the definitive endoderm in mouse is a Smad2-dependent process. Development 127 3079-3090.

Trosset J-Y, Dalvit C, Knapp S, Fasolini M, Veronesi M, Mantegani S, Gianellini LM, Catana C, Sundström M, Stouten PFW et al. 2006 Inhibition of protein-protein interactions: the discovery of druglike beta-catenin inhibitors by combining virtual and biophysical screening. Proteins 64 60-67.

Tsang CK, Qi H, Liu LF \& Zheng XFS 2007 Targeting mammalian target of rapamycin (mTOR) for health and diseases. Drug Discovery Today 12 $112-124$. 
Uchida H, Maruyama T, Nagashima T, Asada H \& Yoshimura Y 2005 Histone deacetylase inhibitors induce differentiation of human endometrial adenocarcinoma cells through up-regulation of glycodelin. Endocrinology $1465365-5373$.

Umezawa K, Ohse T, Yamamoto T, Koyano T \& Takahashi Y 1994 Isolation of a new vinca alkaloid from the leaves of Ervatamia microphylla as an inhibitor of ras functions. Anticancer Research 14 2413-2417.

Umezawa K, Hiroki A, Kawakami M, Naka H, Takei I, Ogata T, Kojima I, Koyano T, Kowithayakorn T, Pang H-S et al. 2003 Induction of insulin production in rat pancreatic acinar carcinoma cells by conophylline. Biomedicine \& Pharmacotherapy 57 341-350.

Vaca P, Berná G, Martín F \& Soria B 2003 Nicotinamide induces both proliferation and differentiation of embryonic stem cells into insulinproducing cells. Transplantation Proceedings 35 2021-2023.

Vaca P, Berná G, Araujo R, Carneiro EM, Bedoya FJ, Soria B \& Martín F 2008 Nicotinamide induces differentiation of embryonic stem cells into insulin-secreting cells. Experimental Cell Research 314 969-974.

Vanhaesebroeck B, Leevers SJ, Ahmadi K, Timms J, Katso R, Driscoll PC, Woscholski R, Parker PJ \& Waterfield MD 2001 Synthesis and function of 3-phosphorylated inositol lipids. Annual Review of Biochemistry 70535.

Villavicencio EH, Walterhouse DO \& Iannaccone PM 2000 The sonic Hedgehog-Patched-Gli pathway in human development and disease. American Journal of Human Genetics 67 1047-1054.

Vincent SD, Dunn NR, Hayashi S, Norris DP \& Robertson EJ 2003 Cell fate decisions within the mouse organizer are governed by graded Nodal signals. Genes and Development 17 1646-1662.

Wang X, Cahill CM, Pineyro MA, Zhou J, Doyle ME \& Egan JM 1999 Glucagon-like peptide-1 regulates the beta cell transcription factor, PDX-1, in insulinoma cells. Endocrinology 140 4904-4907.

Ward S, Sotsios Y, Dowden J, Bruce I \& Finan P 2003 Therapeutic potential of phosphoinositide 3-kinase inhibitors. Chemistry \& Biology 10 207-213.

Watanabe S, Umehara H, Murayama K, Okabe M, Kimura T \& Nakano T 2006 Activation of Akt signaling is sufficient to maintain pluripotency in mouse and primate embryonic stem cells. Oncogene $\mathbf{2 5}$ 2697-2707.

Wells J, Esni F, Boivin G, Aronow B, Stuart W, Combs C, Sklenka A, Leach S \& Lowy A $2007 \mathrm{Wnt} /$ beta-catenin signaling is required for development of the exocrine pancreas. BMC Developmental Biology 74.

Williams JA, Guicherit OM, Zaharian BI, Xu Y, Chai L, Wichterle H, Kon C, Gatchalian C, Porter JA, Rubin LL et al. 2003 Identification of a small molecule inhibitor of the Hedgehog signaling pathway: effects on basal cell carcinoma-like lesions. PNAS 100 4616-4621.
Wolfe MS, Citron M, Diehl TS, Xia W, Donkor IO \& Selkoe DJ 1998 A substrate-based difluoro ketone selectively inhibits Alzheimer's gammasecretase activity. Journal of Medicinal Chemistry 41 6-9.

Wong GT, Manfra D, Poulet FM, Zhang Q, Josien H, Bara T, Engstrom L, Pinzon-Ortiz M, Fine JS, Lee HJ et al. 2004 Chronic treatment with the gamma-secretase inhibitor LY-411,575 inhibits beta-amyloid peptide production and alters lymphopoiesis and intestinal cell differentiation. Journal of Biological Chemistry 279 12876-12882.

Wu X, Walker J, Zhang J, Ding S \& Schultz PG 2004 Purmorphamine induces osteogenesis by activation of the Hedgehog signaling pathway. Chemistry and Biology 11 1229-1238.

Yasunaga M, Tada S, Torikai-Nishikawa S, Nakano Y, Okada M, Jakt LM, Nishikawa S, Chiba T, Era T \& Nishikawa SI 2005 Induction and monitoring of definitive and visceral endoderm differentiation of mouse ES cells. Nature Biotechnology 23 1542-1550.

Yoon J-W \& Jun H-S 2005 Autoimmune destruction of pancreatic beta cells. American Journal of Therapeutics 12 580-591.

Yue F, Cui L, Johkura K, Ogiwara N \& Sasaki K 2006 Glucagon-like peptide1 differentiation of primate embryonic stem cells into insulin-producing cells. Tissue Engineering 12 2105-2116.

Zhang Q, Major MB, Takanashi S, Camp ND, Nishiya N, Peters EC, Ginsberg MH, Jian X, Randazzo PA, Schultz PG et al. 2007 Smallmolecule synergist of the $\mathrm{Wnt} /$ beta-catenin signaling pathway. PNAS $1047444-7448$.

Zhang D, Jiang W, Liu M, Sui X, Yin X, Chen S, Shi Y \& Deng H 2009 Highly efficient differentiation of human ES cells and iPS cells into mature pancreatic insulin-producing cells. Cell Research 19 429-438.

Zhou J, Pineyro MA, Wang X, Doyle ME \& Egan JM 2002 Exendin-4 differentiation of a human pancreatic duct cell line into endocrine cells: involvement of PDX-1 and HNF3beta transcription factors. Journal of Cell Physiology 192 304-314.

Zhu S, Wurdak H, Wang J, Lyssiotis CA, Peters EC, Cho CY, Wu X \& Schultz PG 2009 A small molecule primes embryonic stem cells for differentiation. Cell Stem Cell 4 416-426.

\section{Received in final form 7 April 2010 \\ Accepted 12 April 2010 \\ Made available online as an Accepted Preprint} 12 April 2010 